International Journal of Social Science (IJSS)

Vol.1 Issue.5 February 2022, pp: 747-756

ISSN: 2798-3463 (Printed) | 2798-4079 (Online)

\title{
IMSS-BASED INDONESIAN DEFENSE CONCEPT MAP FOR THE SUNDA STRAIT REGION
}

\author{
By \\ Achmad Abdul Lathif', Suhirwan², Damar Agus Jaya ${ }^{3}$ \\ ${ }^{1,2}$ Department of Defense Management, Faculty of Defense Management, The Republic of Indonesia Defense University, Bogor, \\ Indonesia \\ ${ }^{3}$ Naval Headquarters Airworthiness Office, Naval Headquarters. \\ ${ }^{3}$ Department of Defense Management \\ Email: ${ }^{1}$ achmadabdullathif@gmail.com ${ }^{1}$
}

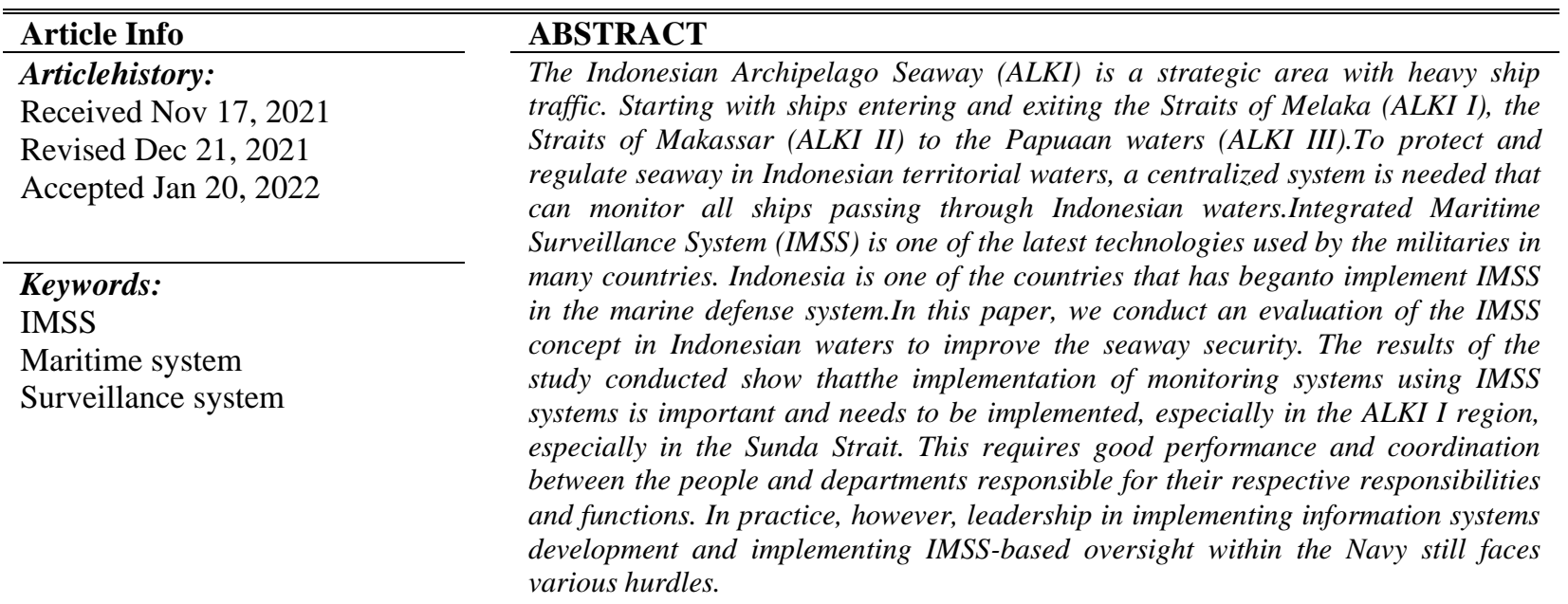

Thisisan open accessarticleundertheCC BY-SAlicense.

CorrespondingAuthor:

Achmad Abdul Lathif

Department of Defense Management, Faculty of Defense Management

The Republic of Indonesia Defense University,

IPSC Area, Sentul, Sukahati, Bogor, Indonesia.

Email: achmadabdullathif@gmail.com

\section{INTRODUCTION}

The Indonesian Archipelago Seaway (ALKI) is a strategic area with heavy ship traffic. Start with ships entering and exiting the Straits of Malacca (ALKI I), the Straits of Makassar (ALKI II) to Papuan waters (ALKI III). For this strategic benefit, the Indonesian Ministry of Defense, together with the Indonesian Navy, has deployed special equipment at various strategic monitoring points. One of them is located in the Sunda Strait. The device is called the Integrated Maritime Surveillance System (IMSS) [7. 8].

IMSS is a maritime surveillance system that is integrated between a coast surveillance station (CSS) or land surveillance station and other surveillance centers. CSS is integrated with Indonesian Warship (KRI), Regional Command Center (RCC) or Regional Control Center and Fleet Command Center (FCC) or Fleet Control Center (Figure 1). [1] 
2

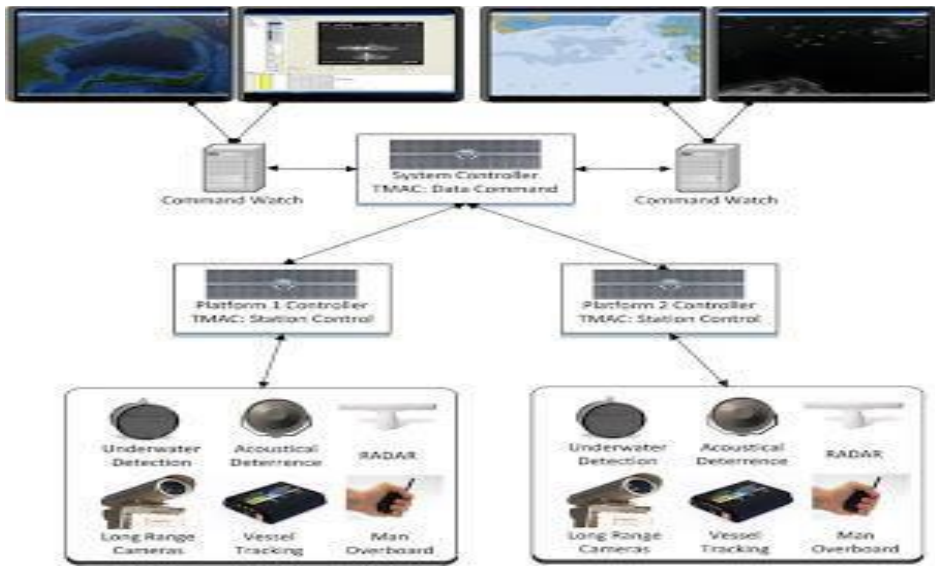

Figure 1. IMSS Maritime System (Source:https://abarky.blogspot.com/2013/05/integrated-maritimesurveillance-syste m.html[7])

The function of the IMSS is to increase maritime awareness, i.e. to protect Indonesian waters, especially those in and out of the Malacca Strait, the Sunda Strait (ALKI I) and the Makassar Strait (ALKI II) by ships in congested areas). The various devices in IMSS (Figure 2) include Radio Detection and Ranging (RADAR), which is used for contact detection (ships) above sea level. $[6,8]$

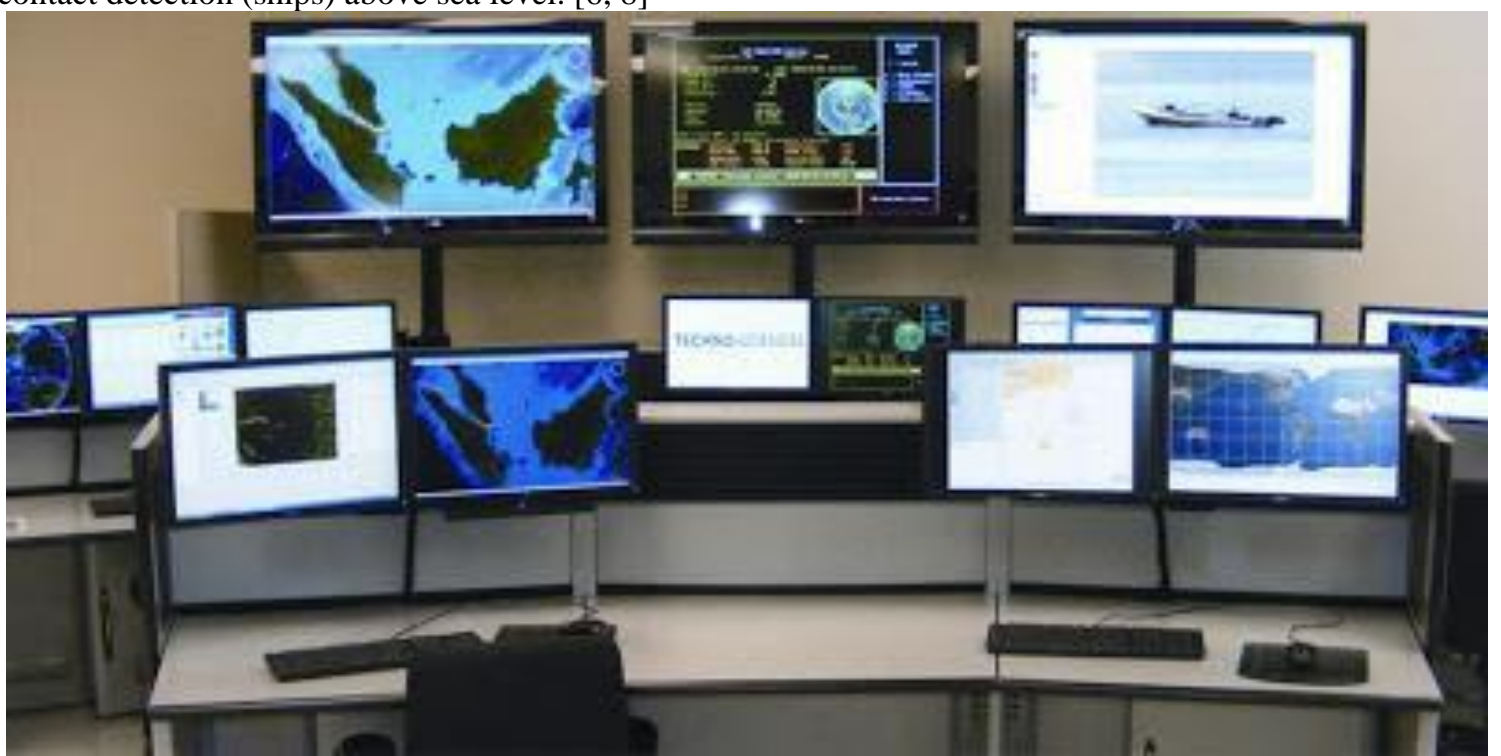

Figure 2. IMSS Devices (Source: https://abarky.blogspot.com/2013/05/integrated-maritime-surveillancesyste m.html[7])

There is also an automatic identification station (AIS) that provides information on the vessel's name and nickname, IMO number, vessel size and type, vessel draught, vessel departure and arrival times, vessel destination, latitude and longitude position, vessel course, and speed. Ships," Danlanal said. The data about ships are always updated on an international scale within a certain period. Therefore, unregistered ships can be defined as unknown ships. Ships with people can still be detected on this radar. IMSS is equipped with VHF radio, which functions as a means of communicating with ships bypassing land monitoring stations Plus HF Radio, as a backup for RCC communication data if VSAT is not available, or as a communication to ships with RCC or via CSS A means of. There is also a day camera (daytime camera) and a FLIR camera (nighttime camera) for taking pictures of ships passing by CSS (m photo) (Figure 3). The camera can be moved directly from RCC or FCC without notifying CSS. 
International Journal of Social Science (IJSS)

Vol.1 Issue.5 February 2022, pp: 747-756

ISSN: 2798-3463 (Printed) | 2798-4079 (Online)

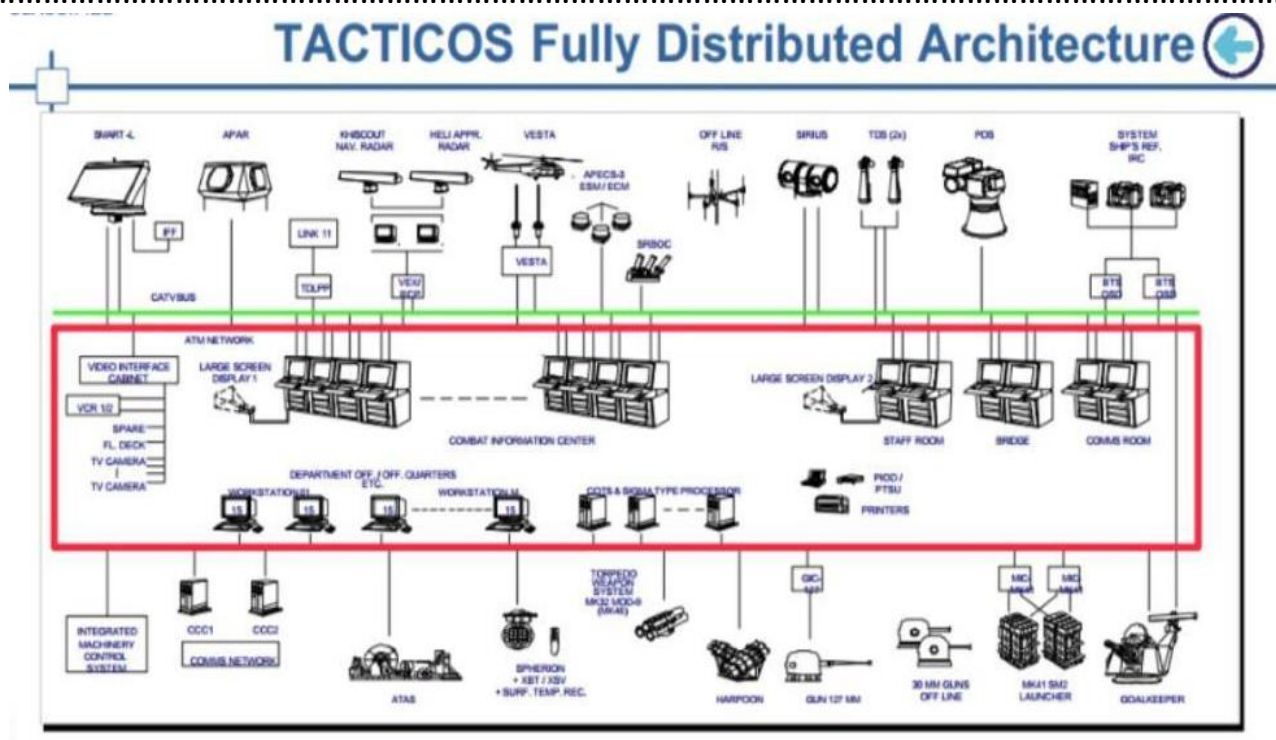

\section{- Distributed Processing \\ - Distributed Sensor \& Weapon Interfaces \\ - Distributed Sensor - Weapon Deployment}

Figure

3.

Tacticos

Fully

Distributed

Architecture

(Source:

https://indonesiacompanynews.wordpress.com/2014/08/27/pt-len-peroleh-kontrak-ekspor-perangkat-lunakkapal-perang/)

Another supporting facility of IMSS is Nobletec, whose function is to monitor the position of ships passing through the CSS and to communicate with the RCC and FCC via a text messaging application. CSS system power comes from two $15 \mathrm{KWh}$ diesel generators.

\section{RESULTS AND DISCUSSION}

IMSS is one of the latest military technology tools. Many countries around the world use it as one of their national defense and security systems. Currently, Indonesia has 20 Coastal Watch Systems (CSS) i.e., 10 in the Strait of Malacca and 10 in the Strait of Makassar. There are also 11 KRIs with IMSS. Three KRIs are attached to the Western Indonesia Regional Fleet Command and eight KRIs are attached to the Eastern Indonesia Regional Fleet Command. Indonesia also has two regional command centers, RCC Batam and RCC Manado, two fleet command centers, FCC Jakarta and FCC Surabaya, and a headquarters (HQ), HQ Cilangkap (Figure 4).
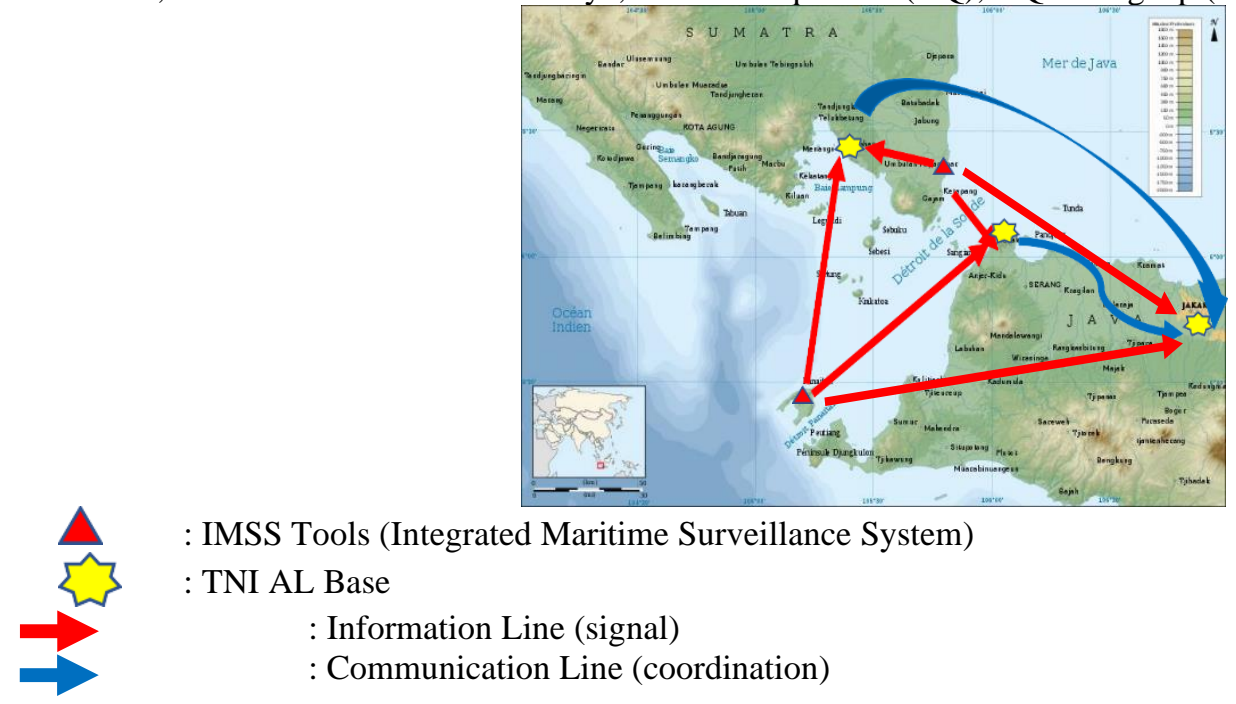

: IMSS Tools (Integrated Maritime Surveillance System)

: TNI AL Base

: Information Line (signal)

: Communication Line (coordination) 
Figure 4. Map of IMSS Information Transfer System.

In order to compile, plan, construct, maintain and develop the Marine Matera state defense information and technology system, various theories and concepts that are supported and related to the system requirements are needed. The threat of non-traditional warfare (NTW) or asymmetric warfare using IT will become more prominent. Considering that this can be done, can happen at any time, and can be carried out by anyone at any place, the most important thing is that they have sufficient facility. Based on these threats, we need network forces with sufficient system defense and security capabilities. The required information system must have the capability to provide information support (Information In War/IIW), information war (IW) and information cooperation (Information Cooperation/IC) in war.In order to realize this interest in its development and development, various theories and concepts are required, including C4ISR, Dekenitetiko, Net-Centric Warfare (NCW) and Net-Centric Operation (NCO) and other related concepts. Detection, surveillance and observation activities are very decisive basic capabilities and advantages to obtain data or phenomena appearing around us, while weather conditions, terrain and enemy intelligence and analysis results are the basic principles of observation orientation in military operations. Therefore, these two aspects need to work together to obtain the best strengths and capabilities. Armies in various developed countries have formed a task force based on this to conduct command and control operations to monitor, manage and control conflict. If the military informatization functions are combined and fully implemented in a certain system, it will be able to improve the quantity and quality of all military operations.In general, the term military information capability is used by militaries around the world to gain the ability to improve information capabilities in all aspects of performing military missions.

C4ISR/K4IPP, and DeKeNiTeTiKo, is a very important concept of activities and capabilities in defense systems, and is a decision-making process based on data collection and processing and utilization of strategic environmental information. [3] This capability is essential in command and control activities where speed and accuracy are very decisive factors considering the limited time required solving various problems and the very wide and complex problems faced

1. C4ISR/K4IPP stands for Command, Control, Communication, Computer, Intelligence, Surveillance, and Reconnaissance. [4] C4ISR is a defensive combat system that provides information capabilities to support the interests of leaders in the decision-making process and consists of a series of monitoring, observation, and reconnaissance processes and activities as well as the communication and cooperation of information about situations and conditions, the collection and processing of data through computers and other ancillary facilities and equipment to support the decision-making process to determine the appropriate object or event of action for a particular event and the implementation of command and control.

2. DeKeNiTeTiKo (in Indonesian Language), which stands for Detect, Recognize, Value, Forward, Action and Command (Figure 5), is a basic concept in the maritime defense combat system and is implemented in the activities of the operational information center (PIT) and command and control center (Puskodal). The Dekenitetiko concept is an indigenous concept proposed and developed by the Indonesian Navy according to the actual needs of maritime operations, so this series of activities marks all the activities that need to be carried out in maritime command and control activities.Dekenitetiko is a series of procedures and activities that Detect, Recognize, Value, Forward, Action and Command an object or event. Surveillance, observation and reconnaissance activities carried out by manual, optical and electronic means collect and process data based on the results of detection activities to provide information for the benefit of leaders to understand the situation and conditions in order to be able to identify and assess an object or event. To support the decision-making process to determine appropriate actions, and to communicate and collaborate with information to transmit information and news in the execution of command and control. 
International Journal of Social Science (IJSS)

Vol.1 Issue.5 February 2022, pp: 747-756

ISSN: 2798-3463 (Printed) | 2798-4079 (Online)

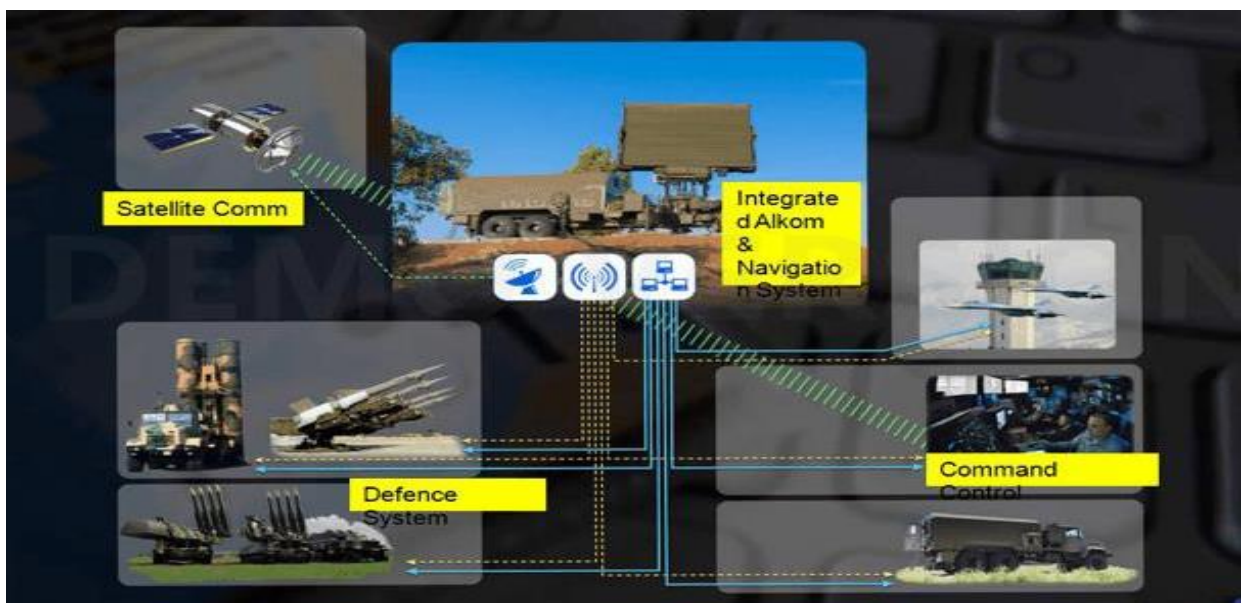

Figure 5. Integrated Communications Tools and Navigation System. (Source:

https://www.hobbymiliter.com/2407/kehebatan-c4isr-sebagai-sistem-pertahanan-indo nesia/. [5])

Puskodal has missions at the strategic, tactical and technical operational command and control level within the Navy, in this case, as an example, the main mission of TNI AL Puskodal, of a strategic nature (Figure 6), including the following missions:

1. The mission of Command and Control (Kodal) is to conduct command and control of operations within the Indonesian Navy, collect, evaluate and process data and provide information, including:

a. Operations and training activities.

b. Stability and operational readiness and composition of the Integrated Fleet Weapons System (SSAT).

c. Strength of non-TNI AL Marines.

d. Potential for non-TNI marine fleet strength.

e. Potential for Maritime Services Industry Capabilities.

f. Naval activities other than warfare.

2. Coordinate with Pusdalops TNI and Puskodal Forces and Polri on various types of operational data and information.

3. Supervise and control the operation of the Indonesian Naval Operational Command Center

4. Prepare operational needs and regulate the readiness of the Puskodal Headquarters.

5. Develop various manuals (Persuasion) in the field of information on operations and training of the Navy.

6. In an emergency, it can be assigned as an alternative to replace the TNI's Pusdalops.

Basic Concepts and Capability of the TNI-AL Puskodal Information System, is a combination of the two concepts that describe activities and utilize the capabilities of C4ISR and the Dekenitetiko concept, in particular the capabilities of facilities and activities, as follows: [2]

1. Command and Control, is the ability of the system to support the activity of delivering instructions/orders containing activities or directives that must be carried out, from the authorized leadertoall related elements/operational units and are within their duties and responsibilities and authorities, orally (voice) or in writing, either directly or indirectly, to take actions, assignments or other activities in overcoming or anticipating a particular problem or event, by using the available communication facilities in the form of radio, telephone, computer network or other facilities available. Owned.

2. Communication is the ability of the system to support the activity of delivering data or multimedia information from one place to another, directly or in stages according to needs and abilities.

3. Computer (Computer) is the ability of the system to support data or information needs through the process of collecting and processing data and presenting multimedia information, for various purposes in supporting all command and control activities.

4. Intelligence is the ability of the system to support data collection, evaluation and analysis of information as a result of intelligence activities which include investigation, security and rising.

Observation and Reconnaissance (Surveilance and Recognation), is the ability of the system to support and carry out detection activities, on an element, target or object as well as certain events at sea, so that it can be detected early and monitored all the time needed, using facilities and equipment which are owned. 
The capability of facilities and equipment as well as the superiority of information owned and produced by a system that adheres to the C4ISR concept, in particular the ability to communicate, computer, intelligence, observation and reconnaissance in an integrated and optimal manner is used to carry out activities of Detection, Recognition, Assessment of certain objects/targets or events. As input in the decision-making process to be able to determine the actions that needs to be taken. The next activity is to continue or communicate using the facilities owned in accordance with the interests and operational needs, in this case is to forward data, information or orders to take actions in the form of command and control for lower units. Detailed activities of how and who detects, recognizes, assesses, proceeds, takes action and gives command will be explained later.

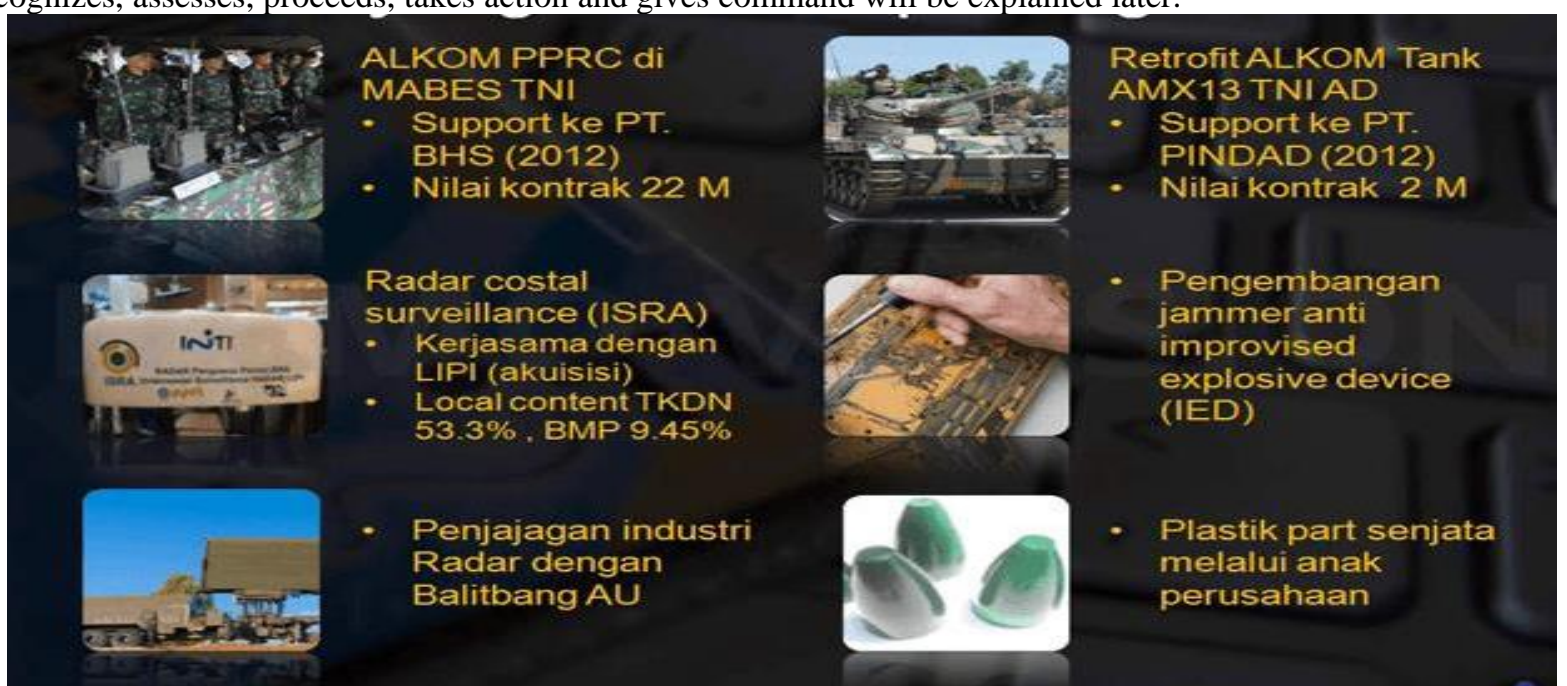

Figure 6. Installed Product / Facility (Source: https://www.hobbymiliter.com/2407/kehebatan-c4isr-sebagai-sistempertahanan-indonesia/. [5])

The implementation of C4ISR / K4IPP, in Dekenitetiko, can generally be seen in Puskodal activities at the technical, tactical and strategic levels. Basically, as previously explained, the two concepts are identical, but in order to facilitate understanding in providing an overview of activities sequentially in the implementation of Puskodal, the activities are adjusted to the activities of Dekenitetiko. So that the activities in C4ISR will be presented as equivalents or similarities to the activities carried out, besides that the facilities and activities in C4ISR will be interpreted as elements or activities in realizing the capabilities carried out in the Dekenitetiko concept, which consists of the following activities:

1. Detection, which has the same meaning and function with Surveillance and Reconnaissance on C4ISR.

a. Activities carried out include observation, reconnaissance and monitoring in order to detect certain elements, targets or objects as well as various events at sea, early.

b. Implementing activities, consisting of Puskodal, RCC (Region Command Center), CSS (Coastal Surveillance System), KRI, Pesud (Maritime Patrol), Posal, Intelligence Operations, Other Operations Elements, TNI Agencies, Non-TNI Agencies (Government/Private), Society, News/Information Domestic/Foreign, etc.

c. The facilities used, according to the equipment owned by each, include Radar, Long Range Camera, Binoculars, Internet, Radio and Satellite, Telephone and other Detection Equipment/Information and Communication Facilities.

2. Recognize, which has the same function with Computer (Computer), detection equipment and Intelligence Data (Intelligent) on C4ISR.

a. Activities carried out include study and research to be able to identify certain Elements, Targets or Objects as well as various events at sea, clearly.

b. Implementing activities, consisting of Puskodal, RCC, CSS and Posal as observers.

c. The facilities used, according to the equipment and facilities owned by each, including AIS (Automatic Information System), LRC (Long Range Camera), computer data processing, to obtain information about objects, targets or events equipped with application systems and data base and other supporters. 
International Journal of Social Science (IJSS)

Vol.1 Issue.5 February 2022, pp: 747-756

ISSN: 2798-3463 (Printed) | 2798-4079 (Online)

DOI: https://doi.org/10.53625/ijjss.v1i5.1319

3. Value, which has the same function as a data processing computer, detection equipment and Intelligence (Intelligent) on C4ISR.

a. Activities carried out consist of data processing, information presentation, evaluation, analysis of the situation and operating conditions of the SSAT (KRI, Pesud, Marines and Bases), as input for the leadership in the decision-making process.

b. The implementer of the activity is the Puskodal.

c. The facilities used are in accordance with the equipment and facilities owned by each Puskodal, including computers complete with application systems that handle such as Operating Environment Information Systems (Silingops) including Intelligence Information Systems, Logistics Information Systems (Silog), Personnel Information Systems (Sipers), Planning, Budgeting and Financial Information System (Sirengarku) and Special Information System (Sispecial) with application system types, in the form of MIS (Management Information System), EIS (Executive Information System), DSS (Decision Support System) and their respective Data Bases and Database on SSAT.

4. Forward, which has the same functions and activities with Communication (Communication), on C4ISR?

a. Activities carried out include communication, regarding various Operational Data and Information, in the form of Voice, Image or Video, Data or Information, Documents and Reports. Carry out Coordination and Reports as well as Cooperation with Pusdalops TNI, Puskodal Forces and the Police as well as Related Agencies (Government/Private) and Communities at home and abroad.

b. The implementer of the activity is the Puskodal.

c. Facilities used, according to the equipment and facilities owned by each Puskodal, including Radio and Satellite, Telephone, Computer and its application system, Video Conference, E-Mail and Internet and Intranet/VPN IP TNI AL, etc.

5. Actions, there are no functions or activities that have anything in common with the C4ISR concept.

a. Activities carried out are activities or actions carried out by the Operations Element/SSAT against certain objects or targets or events, according to orders or commands, where reports of implementation and results of actions are recorded in the database.

b. Implementing activities, consisting of Elements of Operations (SSAT) which includes KRI, Aircraft, Marines and Bases.

c. The facilities used, according to the equipment and facilities as well as the weapons owned are based on the basic functions of each element.

6. Command, which has the same function or activity with Command and Control (Command and Control), in C4ISR.

a. The activity or activity of delivering instructions/orders containing activities or directions that must be carried out, from the authorized leader to all related elements/operational units within their duties and responsibilities and authorities, orally (voice) or in writing, either directly or indirectly. directly, to take actions, assignments or other activities in overcoming or anticipating a certain problem or event, by using the available communication facilities in the form of radio, telephone, computer network or other facilities owned.

b. Executor of activities, Leaders, as Command Holders.

c. The facilities used, according to the equipment and communication facilities owned according to the situation and conditions as well as existing needs and capabilities, such as Radio, Direct Phone, VPN IP, Internet, Intranet etc.

In the application of C4ISR, it can be seen that the intelligence aspect is always integrated with the system in various activities such as detection, recognition and assessment, so that the demands for integration are very prominent. However, in reality what is done within the Navy and TNI is not the case, because intelligence is separate from other aspects and is directly submitted to the leader. Then, the development of defense products is still in the developing stage (Figure 7). 


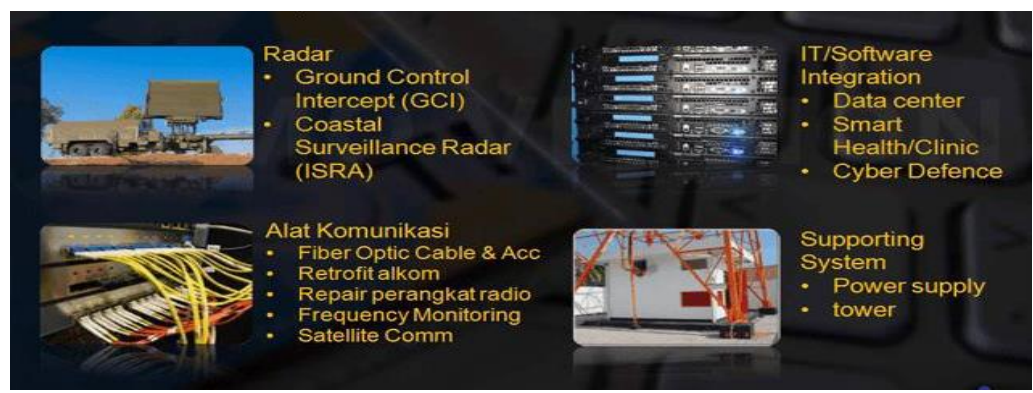

Figure 7. Development of Defense Product (Source: https://www.hobbymiliter.com/2407/kehebatan-c4isr-sebagaisistem-pertahanan-indonesia/. [5])

The problems faced are various limitations that can affect the implementation of information system development within the Navy, including those caused by limitations: [2, 3]

1. Implementation of C4ISR, the Puskodal information system needs to be adjusted wisely, especially regarding the intelligence aspect, because based on theory it is required to integrate with other aspects, while in practice intelligence is separate and directly to the leadership. Therefore, it needs to be discussed thoroughly and straightforwardly in accordance with the real demands of the implementation of the tasks of the Navy.

2. The quality and quantity, behavior and information culture of human resources (HR) for the supervisors and users of the Navy information system, are the most basic and fundamental problems, because the results of all activities will be largely determined by the quality and capabilities of human resources.

3. Infrastructure, so that it has not been able to realize system integration to the lowest level of operating elements. This condition is caused by the unavailability of data communication facilities that are able to support the communication interests of mobile operating elements from sea to land and vice versa.

4. The application system, which supports the success of each task execution activity, is felt to be very minimal, especially to support the interests of operations which are part of information warfare, information warfare and information cooperation.

Systems and Methods, there are still many rules and regulations as well as policies that have not been determined and there are still policies that are over-lap or over-lay in managing certain activities, resulting in various problems in the development of the marine-level state defense information system.

\section{CONCLUSION}

The implementation of a surveillance system using the IMSS system is important and needs to be implemented, especially in the ALKI I area, especially the Sunda Strait. This requires good performance and coordination between personnel and departments in charge of their respective duties and functions. However, in practice there are still various kinds of obstacles faced by the leadership in the implementation of information system development and the implementation of IMSS-based supervision within the Navy. These constraints include:

1. Implementation of C4ISR

2. The quality and quantity

3. Infrastructure

4. The application system

5. Systems and Methods

Seeing from a high level of importance that there will be a need for such a monitoring system, the author's suggestion is that the Indonesian Navy and Indonesian Navy need to prepare all deficiencies and cover existing obstacles so that the implementation of IMSS-based supervision can be realized.

\section{REFERENCE}

[1] LaksdaTNIDr.Suhirwan,S.T.,M.MT. Materi pembelajaran dosen Sistem Teknologi Pertahanan Laut.

[2] https://manantoz.wordpress.com/penerapan-sistem-c4isr-pada-siskomdal-tni/accessed on 09 June 2020.

[3] https://id.scribd.com/document/323704175/IMPLEMENTASI-C4ISR accessed on 09 June 2020.

[4] https://jakartagreater.com/113592/c4isr-command-control-communicationcomputerintell egence-surveilanceand-reconnaisance-tni/ accessed on 09 June 2020. 
International Journal of Social Science (IJSS)

Vol.1 Issue.5 February 2022, pp: 747-756

ISSN: 2798-3463 (Printed) | 2798-4079 (Online)

crossref DOI: https://doi.org/10.53625/ijss.v1i5.1319

[5] https://www.hobbymiliter.com/2407/kehebatan-c4isr-sebagai-sistem-pertahanan-indones ia/ accessed on 25 January 2022.

[6] http://defensestudies.blogspot.com/2010/01/tni-al-optimalkan-penggunaan-radar.html accessed on 09 June 2020.

[7] https://abarky.blogspot.com/2013/05/integrated-maritime-surveillance-system.html accessed on 09 June 2020. 